\title{
Atrial Natriuretic Factor in Human Blood
}

Tohru Yamaji, Miyuki Ishibashi, and Fumimaro Takaku

Third Department of Internal Medicine, Faculty of Medicine, University of Tokyo, Hongo, Tokyo, Japan

\begin{abstract}
To determine whether atrial natriuretic factor (ANF) is a circulating hormone in men, a radioimmunoassay suitable for the estimation of ANF in human plasma was developed and the nature of plasma ANF was characterized. Plasma ANF was extracted before radioimmunoassay by affinity chromatography on a column of ANF antibody-coupled agarose. When plasma ANF extract was analyzed by sodium dodecyl sulfate-polyacrylamide gel electrophoresis, with the radioimmunoassay of the eluted gel slices for ANF, almost all of the ANF activities ran in the 3,000mol-wt area, while three peaks of ANF were observed in human atrial tissue extract, molecular weights of which corresponded to $14,000,6,000$, and 3,000 , respectively. Reversed-phase high performance liquid chromatography of atrial tissue extract resolved multiple forms of ANF. In contrast, one major peak was observed in human plasma extract, and its retention time coincided with that of synthetic human $\alpha$-atrial natriuretic polypeptide. When $500 \mathrm{ml}$ of $0.9 \%$ saline was infused into six healthy subjects over $45 \mathrm{~min}$, plasma levels of ANF were unequivocally elevated. The mean plasma ANF concentrations rose from the baseline $(23.0 \pm 2.5 \mathrm{pg} / \mathrm{ml}$, mean $\pm \mathrm{SEM}, n=6)$ to the peak $(41.8 \pm 4.9 \mathrm{pg} / \mathrm{ml}$, mean $\pm \mathrm{SEM})$ at $75 \mathrm{~min}$ postinfusion. No significant change in plasma ANF, on the other hand, was found in the control group. These results suggest that ANF is a circulating hormone in men and is secreted in response to isotonic volume expansion.
\end{abstract}

\section{Introduction}

Mammalian atria contain specific granules which are very similar to secretory granules in endocrine cells $(1,2)$. The number of atrial granules appears to be altered by changes in electrolyte and fluid balance (3). Recently, a biologically active peptide, atrial natriuretic factor (ANF), ${ }^{1}$ has been isolated from the atria of men and rats, sequenced, and synthesized (4-11). The peptide was shown to possess many important biological actions including natriuretic, diuretic (12), and smooth muscle relaxant

Address requests for reprints to Dr. Tohru Yamaji, Third Department of Internal Medicine, Faculty of Medicine, University of Tokyo, 7-3-1 Hongo, Bunkyo-ku, Tokyo 113, Japan.

Received for publication 18 June 1985.

1. Abbreviations used in this paper: ANF, atrial natriuretic factor; hANP, $\alpha$-human atrial natriuretic polypeptide; HPLC, high performance liquid chromatography.

J. Clin. Invest.

(c) The American Society for Clinical Investigation, Inc.

0021-9738/85/10/1705/05 \$1.00

Volume 76, October 1985, 1705-1709 activities (13). A bolus injection of ANF to men resulted in an immediate and striking increase in urinary sodium excretion and urine volume (14), which suggests that the atria may be part of an endocrine system in men. Whether or not ANF is secreted from human atria into the bloodstream, however, is unknown. The present study was undertaken to develop the radioimmunoassay suitable for the estimation of ANF in human plasma, to examine the changes of the circulating levels of ANF in response to body fluid expansion, and to characterize the nature of the peptide in human blood.

\section{Methods}

Subjects. 11 male control subjects were healthy volunteers aged between 21 and 23 yr. None of the subjects received any medication. Studies were performed in the morning after an overnight fast. The subjects were kept in a recumbent position for at least $30 \mathrm{~min}$ before and throughout the study. Blood samples were collected at 15-min intervals for $2 \mathrm{~h}$ through an indwelling catheter placed in an antecubital vein into a chilled heparinized tube. In six subjects, $500 \mathrm{ml}$ of $0.9 \%$ saline was infused over 45 min through a second intravenous cannula inserted in the opposite arm. Heart rate as well as blood pressure measured at the time of the cessation of the infusion and at the termination of the study was not significantly changed from the control. Hematocrit of each blood sample was determined, and plasma was quickly separated by centrifugation and stored at $-20^{\circ} \mathrm{C}$ until processed.

Radioimmunoassay. $1 \mathrm{mg}$ of synthetic $\alpha$-human atrial natriuretic polypeptide (hANP) (10) (Peninsula Laboratories, Inc., Belmont, CA) was conjugated to $1 \mathrm{mg}$ of bovine serum albumin (BSA) with 1-ethyl-3 (dimethyl aminopropyl) carbodiimide (Sigma Chemical Co., St. Louis MO) (15). After dialysis against $0.9 \%$ saline, conjugated hANP was emulsified with an equal volume of complete Freund's adjuvant (Difco Laboratories Inc., Detroit, MI) and injected intradermally into 20-30 sites in female Albino rabbits at a month's interval. Each injection contained the conjugate equivalent to $50 \mu \mathrm{g}$ of unconjugated hANP. Blood was drawn 2 wk after booster injections and tested for antibody.

Synthetic hANP was labeled with ${ }^{125}$ I by a modification of the chloramine $T$ method (16). The addition of sodium metabisulfite was omitted in order to avoid the reduction of the disulfide bond of hANP. The reaction mixture was applied to a $0.7 \times 20$-cm column of Sephadex G-25 superfine and eluted with $0.01 \mathrm{M}$ acetic acid containing $0.5 \% \mathrm{BSA}$. Fractions that corresponded to ${ }^{125} \mathrm{I}$-labeled hANP were collected and ${ }^{125}$ I-hANP was further purified by high performance liquid chromatography (HPLC).

A radioimmunoassay technique previously described in detail for arginine vasopressin (17) was employed in this study. Varying amounts of unlabeled hANP or plasma extracts were placed in each tube and an appropriate amount of $0.01 \mathrm{M}$ phosphate, $0.14 \mathrm{M}$ sodium chloride, $\mathrm{pH}$ 7.0 (phosphate-buffered saline, PBS) including $1 \%$ BSA, $0.1 \%$ Triton X100 , and $500 \mathrm{U} / \mathrm{ml}$ aprotinin (Antagosan, Hoechst Japan, Ltd., Tokyo, Japan) was added to yield a volume of $200 \mu \mathrm{l} .100 \mu \mathrm{l}$ of the antiserum diluted with $0.05 \mathrm{M}$ EDTA in PBS containing $0.5 \%$ nonimmune rabbit serum was added to each tube, an amount capable of binding 40-50\% of the total radioactivity associated with ${ }^{125} \mathrm{I}-\mathrm{hANP}$. The tubes were incubated at $4^{\circ} \mathrm{C}$ for $24 \mathrm{~h}$ and then 5-10 pg of ${ }^{125} \mathrm{I}-\mathrm{hANP}$ (equivalent to 
$\sim 4,000 \mathrm{cpm}$ ) in $50 \mu \mathrm{l}$ of the assay buffer was added. $24 \mathrm{~h}$ after the addition of the labeled hANP, a sufficient amount of anti-rabbit gamma globulin serum was added, which maximally precipitated the rabbit gamma globulin. The incubation was continued for an additional $48 \mathrm{~h}$ at $4^{\circ} \mathrm{C}$. The tubes were centrifuged, the supernate was decanted, and the radioactivity in the precipitates was counted in an auto-gamma spectrometer. The results are expressed in terms of the immunoactivities of hANP.

Extraction of ANF from human plasma. ANF was extracted from plasma by means of affinity chromatography on hANP antibody-coupled agarose. Immunoglobulin $\mathrm{G}$ fraction of anti-hANP serum was separated by protein-A Sepharose (Pharmacia Fine Chemicals, Uppsala, Sweden) and coupled to cyanogen bromide Sepharose 4B (Pharmacia Fine Chemicals) according to the method of Cuatrecasas et al. (18). The resulting gel was packed in a small column (total volume: $0.1 \mathrm{ml}$ ) and equilibrated with PBS. $1 \mathrm{ml}$ of plasma, to which an equal volume of PBS and 1,000 U/ml of aprotinin (Hoechst Japan Ltd.) were previously added, was applied to the anti-hANP-Sepharose column. The column was washed with $2 \mathrm{ml}$ of PBS and eluted with $0.7 \mathrm{ml}$ of $1 \mathrm{M}$ acetic acid containing $1 \mathrm{mg} / \mathrm{ml} \mathrm{BSA}$. The eluates were lyophilized, reconstituted with $0.25 \mathrm{ml}$ of the assay buffer, and $0.1-\mathrm{ml}$ aliquots were subjected to radioimmunoassay.

Extraction of ANF from human atrial tissue. Human right auricle tissue was obtained from a patient with mitral steno-insufficiency during surgery for mitral valve replacement. The tissue was immediately frozen on dry ice and stored at $-80^{\circ} \mathrm{C}$ until extraction. On the day of extraction, the tissue was sectioned while still frozen and boiled for $5 \mathrm{~min}$ in $10 \mathrm{vol}$ of $1 \mathrm{M}$ acetic acid containing $20 \mathrm{mM} \mathrm{HCl}$. After cooling, the tissue was extracted on ice by homogenization with a Polytron mixer (Polytron Corp., Elkhart, IN).

Sodium dodecyl sulfate (SDS)-polyacrylamide gel electrophoresis. ANF was extracted from $150 \mathrm{ml}$ of human plasma pool by affinity chromatography on anti-hANP-Sepharose and lyophilized. An aliquot of the sample was dissolved in $8 \mathrm{M}$ urea- $1.5 \%$ SDS- $0.01 \mathrm{M}$ phosphate buffer (pH 7.0) at $70^{\circ} \mathrm{C}$ for $30 \mathrm{~min}$ and subjected to SDS-polyacrylamide gel electrophoresis. Reducing agents were avoided to prevent loss of ANF immunoreactivity. SDS-polyacrylamide gel electrophoresis (15\% acrylamide-0.4\% $N, N^{\prime}$-methylene bisacrylamide) was performed using gel tubes of $10 \times 0.5 \mathrm{~cm}$. The running buffer was $0.1 \mathrm{M}$ phosphate- $0.1 \%$ SDS (pH 7.0) $(19,20)$. Molecular weight markers used were BSA, egg albumin, trypsin inhibitor, cytochrome $c$, aprotinin, insulin $B$ chain, and ${ }^{125}$ I-labeled hANP. Each sample contained cytochrome $c$ and ${ }^{125}$ I-labeled hANP as internal markers. After electrophoresis, gels were cut into 2$\mathrm{mm}$ slices followed by elution into the assay buffer by mixing at room temperature overnight.

HPLC of atrial and plasma ANF. Reverse-phase HPLC of atrial and plasma extracts was performed on a $4.6 \times 250-\mathrm{mm}$ column of octadecylsilane (TSK gel ODS 120A, Toyosoda, Tokyo, Japan). The solvents used were $\mathrm{H}_{2} \mathrm{O}$ /acetonitrile/10\% trifluoroacetic acid, 90:10:1 (A), and $\mathrm{H}_{2} \mathrm{O} /$ acetonitrile/10\% trifluoroacetic acid, 40:60:1 (B). A linear gradient elution system was employed from solvent $A$ to $B$ over $80 \mathrm{~min}$. The flow rate was $1.0 \mathrm{ml} / \mathrm{min}$ and each $1-\mathrm{ml}$ fraction was collected. Fractions were lyophilized, reconstituted with the assay buffer, and assayed for ANF by radioimmunoassay.

Statistical analysis. Values in figures and text are given as the mean \pm SEM. The significance of differences was calculated using Student's $t$ test.

\section{Results}

Validity of the radioimmunoassay. All of the three rabbits immunized developed a high titer antibody for hANP. One of the antisera that possessed the best avidity was selected and used for further studies. This antiserum could bind $40-50 \%$ of ${ }^{125} \mathrm{I}$ labeled hANP added at a final dilution of 53,000. Fig. 1 illustrates a variety of dose-response curves constructed by hANP and its related peptides. At $90 \%$ of the buffer control tubes, the assay detected as little as $5 \mathrm{pg}$ of synthetic hANP (Peninsula Labo-

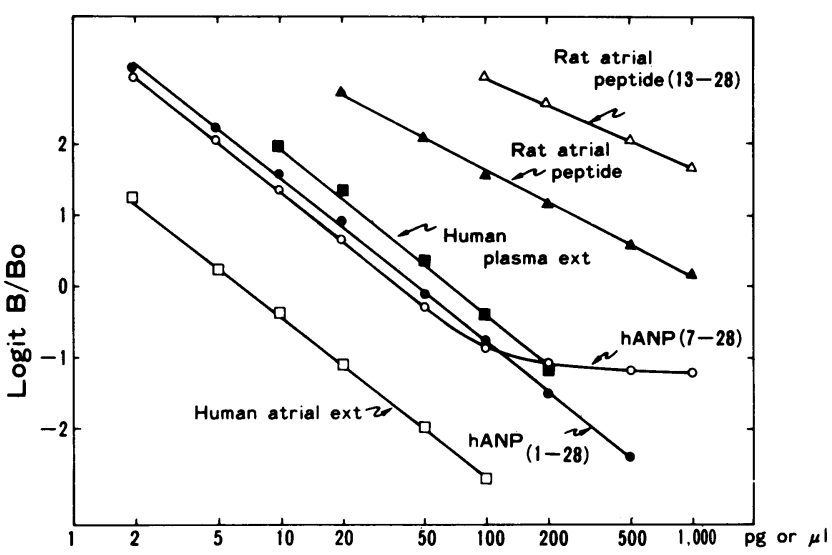

Figure 1. Dose-response curves of hANP and its related peptides as well as human atrial and plasma extracts in the ANF radioimmunoassay. The picograms of peptides and microliters of extracts are plotted on the abscissa on a logarithmic scale and logit $\mathbf{B} / \mathbf{B}_{0}$ on the ordinate.

ratories) and the $50 \%$ intercept was at $45 \mathrm{pg}$. Human atrial extract exhibited a dose-response curve parallel with that of hANP. Synthetic hANP (7-28) (Peninsula Laboratories), on the other hand, showed a dose-response curve with a different shape and slope, while higher doses of synthetic rat atrial peptide (1-28) (4) and rat atrial peptide (13-28) (Peninsula Laboratories) were required for the significant displacement of ${ }^{125} \mathrm{I}$-labeled hANP from the antibody. The results suggest that the antiserum mainly recognizes the first 12 amino acid sequences of hANP.

Basal ANF levels in human plasma. Initially, we attempted to determine ANF in unextracted human plasma. Plasma levels of ANF in healthy subjects were estimated to be $475 \pm 38 \mathrm{pg} / \mathrm{ml}$ (mean \pm SEM, $n=8$ ) by the direct assay method; however, similar values were obtained when ANF-free human plasma prepared by eliminating ANF with an anti-hANP-coupled Sepharose column was added to the radioimmunoassay. This suggests the degradation of ${ }^{125} \mathrm{I}$-labeled hANP during incubation by proteolytic enzymes present in human plasma. It was decided, therefore, to extract ANF from human plasma by means of affinity chromatography on anti-hANP-coupled Sepharose before radioimmunoassay. The recovery of hANP from plasma by this method was $80.7 \pm 1.0 \%$ (mean \pm SEM, $n=37$ ), when $1 \mathrm{ml}$ of the outdated blood bank plasma, to which 200 pg of synthetic hANP was added, was subjected to affinity chromatography and radioimmunoassayed. The coefficients of variation averaged $7.2 \%$ for intraassay error and $11.1 \%$ for interassay error. The dose-response curve constructed by human plasma extract was parallel with that of synthetic hANP (Fig. 1). Plasma ANF levels of 26 healthy adults on ad lib. water intake were $34.8 \pm 2.3 \mathrm{pg} / \mathrm{ml}$ (mean \pm SEM), while the plasma concentrations of ANF in 25 control subjects after overnight dehydration were $28.5 \pm 2.8$ $\mathrm{pg} / \mathrm{ml}$ (mean $\pm \mathrm{SEM}$ ). The mean ANF values of both groups were not statistically different.

Response of plasma ANF levels to isotonic volume expansion. In Fig. 2 are illustrated the changes of plasma ANF levels after infusion of $500 \mathrm{ml}$ of $0.9 \%$ saline in six healthy men. The hematocrit of each subject declined after the infusion began and reached the nadir at $45 \mathrm{~min}$ when the mean $( \pm$ SEM) decrement of hematocrit was $6.4 \pm 0.4 \%$ of the control. Plasma levels of ANF, on the other hand, began to rise during infusion and further increased after the infusion ended. The peak plasma ANF concentration ranged from 181 to $221 \%(197 \pm 6 \%$, mean \pm SEM) of the baseline. In some subjects (Nos. 1, 2, and 5), the levels tended 


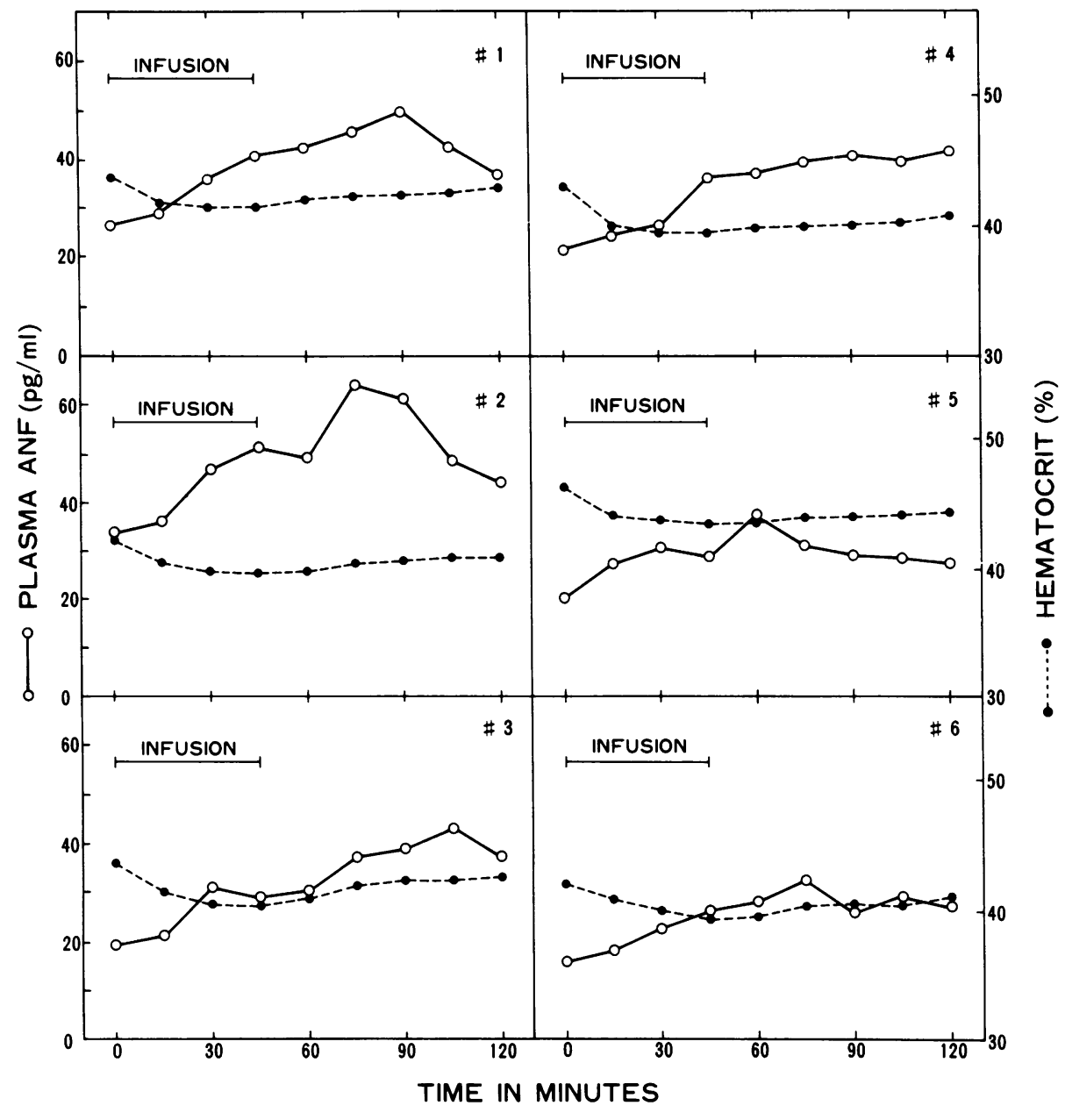

Figure 2. Changes in plasma ANF levels (solid lines) and hematocrit (dotted lines) after the infusion of $0.9 \%$ saline in six healthy subjects. Saline $(500 \mathrm{ml})$ was infused over $45 \mathrm{~min}$. to decrease after reaching the peak between 60 and $90 \mathrm{~min}$; however, this decrease in plasma ANF levels was not evident in the remainder during the period of observation.

Fig. 3 shows the composite of the changes of plasma ANF levels after saline infusion in six subjects described above and, in addition, the spontaneous fluctuation of ANF levels in five healthy men who did not receive the infusion. In the infusion group, the mean plasma ANF concentrations increased from the baseline $(23.0 \pm 2.5 \mathrm{pg} / \mathrm{ml}$, mean \pm SEM $)$ to the peak $(41.8 \pm 4.9$ $\mathrm{pg} / \mathrm{ml}$, mean \pm SEM) at $75 \mathrm{~min}$. The mean ANF levels at $45 \mathrm{~min}$ and thereafter were significantly higher $(P<0.01$ at $60,75,105$, and $120 \mathrm{~min}$, and $P<0.05$ at 45 and $90 \mathrm{~min}$ ) than the mean basal ANF concentration, respectively. In contrast, plasma ANF levels in the control group did not show a significant change.

Characterization of ANF in human plasma. Analysis of ANF in pooled human plasma extract by SDS-polyacrylamide gel electrophoresis, with the radioimmunoassay of the eluted gel slices for ANF, is shown in Fig. $4 \mathrm{~B}$. For comparison, the migration pattern of SDS-gel electrophoresis of immunoreactive ANF in human atrial tissue is depicted in Fig. $4 \mathrm{~A}$. In atrial tissue, three major peaks of ANF were observed, molecular weights of which corresponded to $14,000,6,000$, and 3,000 , respectively. In human plasma extract, on the other hand, almost all of the ANF activities ran in the 3,000-mol wt area of the gel, although a small peak was observed in the 14,000 -mol-wt region.

Reversed-phase HPLC of human atrial tissue extract resolved multiple peaks of ANF (Fig. $5 A$ ). In contrast, one major peak was observed in plasma ANF (Fig. $5 \mathrm{~B}$ ). The retention time of this plasma ANF peak coincided with that of one of the ANF peaks in atrial tissue extract and, in addition, with that of synthetic hANP. Several minor peaks were also found, the identities of which are at present unknown. On the basis of their elution

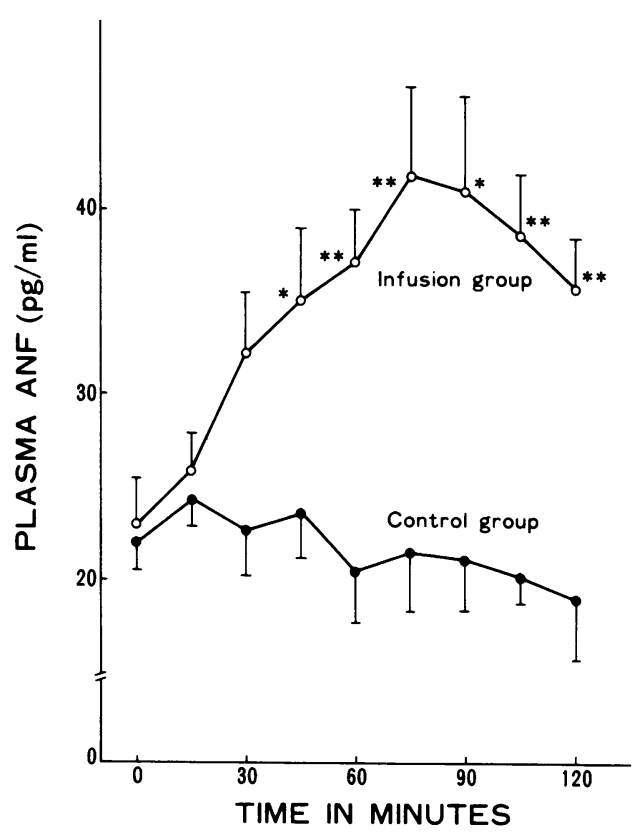

Figure 3. Mean $( \pm$ SEM) plasma concentrations of ANF in six healthy subjects after the infusion of $0.9 \%$ saline and in five healthy subjects who served as controls. Saline $(500 \mathrm{ml})$ was infused over $45 \mathrm{~min} .{ }^{*}, P$ $<0.05 ;{ }^{* *}, P<0.01$ vs control. 


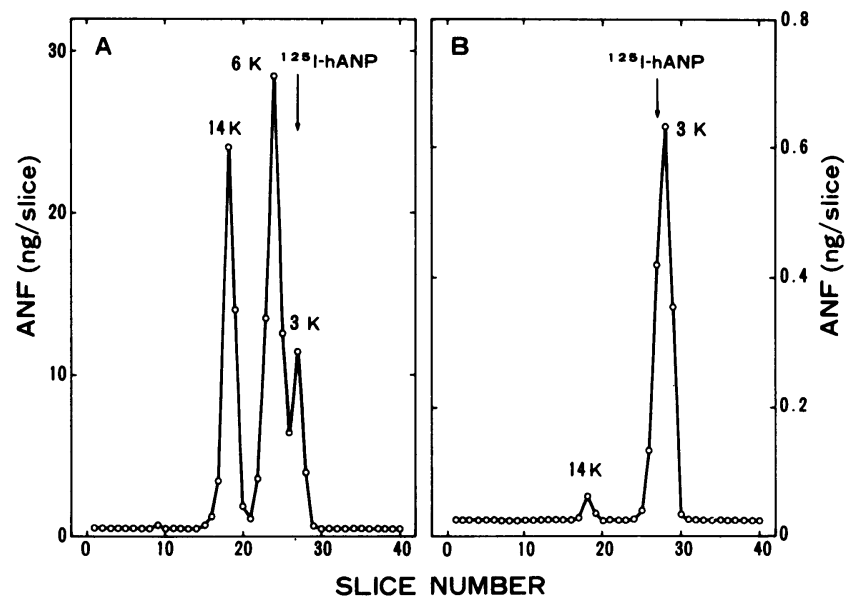

Figure 4. Electrophoretic analyses, in SDS-polyacrylamide gels, of the immunoreactive ANF in human atrial tissue extract $(A)$ and in plasma extract $(B) .14 \mathrm{~K}$ denotes the $14,000-, 6 \mathrm{~K}$ the $6,000-$, and $3 \mathrm{~K}$ the 3,000 -mol wt region, respectively. Arrows indicate the peak of ${ }^{125} \mathrm{I}$-labeled hANP added to the samples as an internal marker.

patterns, two major peaks in atrial tissue extract may correspond to $\beta$-hANP and $\gamma$-hANP $(10,11)$, respectively.

\section{Discussion}

The foregoing results clearly show that ANF exists in human plasma. The molecular weight of ANF in human plasma is 3,000 and its retention time on reverse phase HPLC is identical to that of synthetic hANP. Although 14,000-mol wt and 6,000mol wt hANP, which may correspond to $\gamma$ - and $\beta$-hANP (10, $11)$, respectively, were found in greater quantities than 3,000mol-wt ANF in human atrial tissue, only a minute amount of these high molecular weight forms of ANF was detected in human plasma. The result suggests that almost all human proANF (11) may be completely processed before exocytosis, or alternatively, that pro-ANF secreted may receive the subsequent degradation in the circulation. In the rabbit, the coronary venous effluent obtained from isolated perfused heart only contained the low molecular weight form of natriuretic factor (21). If this were the case in men, the former view may be more likely. In addition to the major peak, a small amount of plasma ANF was eluted in the more polar fractions on HPLC. In view of the findings that suggest microheterogeneity of atrial natriuretic factors in the rat depending upon the degree of the deletion of the $\mathrm{COOH}$-terminal or the $\mathrm{NH}_{2}$-terminal amino acids (4-9), these peaks may represent ANF that lacks a few amino acids at the terminus with identical sequences over a central core region.

Plasma ANF levels in the circulation of men are unexpectedly low. This is in contrast with the abundance of this peptide in human atrial tissue. ANF levels in rat plasma were reported to be more than 10 times higher $(22,23)$ than the plasma levels of men demonstrated in this study. This may be ascribed to a species difference. However, Lang et al. (24) recently reported the mean plasma concentration of ANF in barbiturate-anesthetized rats was $55 \mathrm{pg} / \mathrm{ml}$, which approximates to human plasma levels obtained in the present study.

Administration of $500 \mathrm{ml}$ of saline to six healthy men unequivocally resulted in a twofold increase in plasma ANF levels. The response was prompt and continued after the infusion ended.

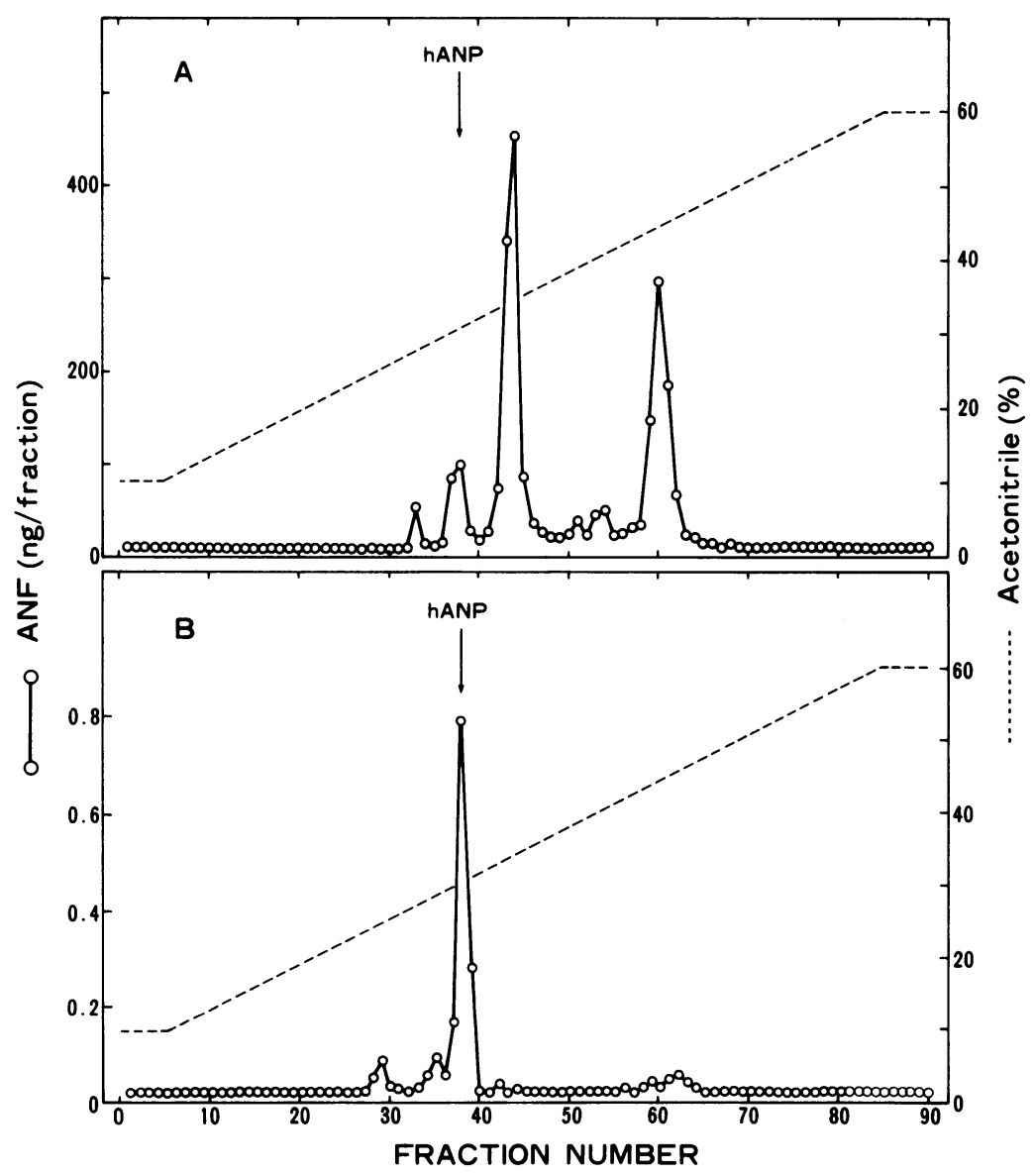

Figure 5. Analyses of the immunoreactive ANF in human atrial tissue extract $(A)$ and in plasma extract $(B)$ by reverse-phase HPLC. A linear gradient system was used from 10 to $60 \%$ acetonitrile over $80 \mathrm{~min}$. The flow rate was $1.0 \mathrm{ml} / \mathrm{min}$ and each $1-\mathrm{ml}$ fraction was collected. Arrows indicate the elution position of synthetic hANP. 
It may be argued that the rise in plasma ANF levels is not due to the saline infusion, but reflects spontaneous fluctuation. However, this may not be likely, since plasma ANF levels did not show any signficant change in the control group. It was concluded from these results that the secretion of ANF from the human atria was stimulated by isotonic volume expansion. In support of this view, the mean plasma ANF concentration of healthy subjects on ad lib. water intake was higher than that of men dehydrated overnight, although the difference was not statistically significant.

In conclusion, the present study demonstrates that ANF is a circulating hormone in men and is secreted in response to volume expansion. Very recently, Genest and his colleagues (25), and we (26) independently observed that plasma ANF levels are increased in paroxysmal atrial tachycardia. Whether ANF is involved in the physiology or pathophysiology of water and electrolyte metabolism in men may be the subject of future studies.

\section{Acknowledgments}

The authors are indebted to Professor K. Asano and his colleagues, Department of Thoracic Surgery, Faculty of Medicine, University of Tokyo, for providing us with auricle tissue.

\section{References}

1. Kisch, B. 1956. Electron microscopy of the atrium of the heart. Exp. Med. Surg. 14:99-112.

2. Jamieson, J. D., and G. E. Palade. 1964. Specific granules in atrial muscle cells. J. Cell Biol. 23:151-172.

3. De Bold, A. J. 1979. Heart atria granularity effects of changes in water-electrolyte balance. Proc. Soc. Exp. Biol. Med. 161:508-511.

4. Flynn, T. G., M. L. de Bold, and A. J. de Bold. 1983. The amino acid sequence of an atrial peptide with potent diuretic and natriuretic properties. Biochem. Biophys. Res. Commun. 117:859-865.

5. Currie, M. G., D. M. Geller, B. R. Cole, N. R. Siegel, K. M. Fok, S. R. Adams, S. R. Eubanks, G. R. Gallupi, and P. Needleman. 1984. Purification and sequence analysis of bioactive atrial peptides (atriopeptins). Science (Wash. DC). 223:67-69.

6. Seidah, N. G., C. Lazure, M. Chretien, G. Thibault, R. Garcia, M. Cantin, J. Genest, R. F. Nutt, S. F. Brady, T. A. Lyle, W. J. Paleveda, C. D. Colton, T. M. Ciccarone, and D. F. Veber. 1984. Amino acid sequence of homologous rat atrial peptides: natriuretic activity of native and synthetic forms. Proc. Natl. Acad. Sci. USA. 81:2640-2644.

7. Geller, D. M., M. G. Currie, K. Wakitani, B. R. Cole, S. P. Adams, K. F. Fok, N. R. Siegel, S. R. Eubanks, G. R. Gallupi, and P. Needleman. 1984. Atriopeptins: a family of potent biologically active peptides derived from mammalian atria. Biochem. Biophys. Res. Commun. 120:333-338.

8. Kangawa, K., A. Fukuda, I. Kubota, Y. Hayashi, and H. Matsuo. 1984. Identification in rat atrial tissue of multiple forms of natriuretic polypeptides of about 3,000 daltons. Biochem. Biophys. Res. Commun. 121:585-591.

9. Misono, K. S., R. T. Grammer, H. Fukumi, and T. Inagami. 1984.
Rat atrial natriuretic factor: isolation, structure and biological activities of four major peptides. Biochem. Biophys. Res. Commun. 123:444-451.

10. Kangawa, K., and H. Matsuo. 1984. Purification and complete amino acid sequence of $\alpha$-human atrial natriuretic polypeptide ( $\alpha$-hANP). Biochem. Biophys. Res. Commun. 118:131-139.

11. Kangawa, K., A. Fukuda, and H. Matsuo. 1985. Structural identification of $\beta$ - and $\gamma$-human atrial natriuretic polypeptides. Nature (Lond.). 313:397-400.

12. De Bold, A. J., H. B. Borenstein, A. T. Veress, and H. Sonnenberg. 1981. A rapid and potent natriuretic response to intravenous injection of atrial myocardial extract in rats. Life Sci. 28:89-94.

13. Currie, M. G., D. M. Geller, B. R. Cole, J. G. Boylan, W. Yusheng, S. W. Holmberg, and P. Needleman. 1983. Bioactive cardiac substances: potent vasorelaxant activity in mammalian atria. Science (Wash. DC). 221:71-73.

14. Richards, A. M., M. G. Nicholis, H. Ikram, M. W. I. Webster, T. G. Yandle, and E. A. Espiner. 1985. Renal, haemodynamic, and hormonal effects of human alpha atrial natriuretic peptides in healthy volunteers. Lancet. i:545-549.

15. Goodfriend, T., L. Levine, and G. Fasman. 1964. Antibodies to bradykinin and angiotensin: a use of carbodiimides in immunology. Science (Wash. DC). 144:1344-1346.

16. Greenwood, F. C., W. M. Hunter, and J. S. Glover. 1963. The preparation of ${ }^{131}$ I-labeled human growth hormone of high specific activity. Biochem. J. 89:114-123.

17. Shimamoto, K., T. Murase, and T. Yamaji. 1976. A heterologous radioimmunoassay for arginine vasopressin. J. Lab. Clin. Med. 87:338344.

18. Cuatrecasas, P., M. Wilchek, and C. B. Anfinsen. 1968. Selective enzyme purification by affinity chromatography. Proc. Natl. Acad. Sci. USA. 61:636-643.

19. Shapiro, A. L., E. Vinuela, and J. V. Maizel, Jr. 1967. Molecular weight estimation of polypeptide chains by electrophoresis in SDS-polyacrylamide gels. Biochem. Biophys. Res. Commun. 28:815-820.

20. Weber, K., and M. Osborn. 1969. The relationship of molecular weight determinations by dodecyl-sulfate-polyacrylamide gel electrophoresis. J. Biol. Chem. 244:4406-4412.

21. Currie, M. G., D. Sukin, D. M. Geller, B. R. Cole, and P. Needleman. 1984. Atriopeptin release from the isolated perfused rabbit heart. Biochem. Biophys. Res. Commun. 124:711-717.

22. Tanaka, I., K. S. Misono, and T. Inagami. 1984. Atrial natriuretic factor in rat hypothalamus, atria and plasma: determination by specific radioimmunoassay. Biochem. Biophys. Res. Commun. 124:663-668.

23. Gutkowska, J., K. Horky, G. Thibault, P. Januszewicz, M. Cantin, and J. Genest. 1984. Atrial natriuretic factor is a circulating hormone. Biochem. Biophys. Res. Commun. 125:315-323.

24. Lang, R. E., H. Tholken, D. Ganten, F. C. Luft, H. Ruskoacho, and Th. Unger. 1985. Atrial natriuretic factor: a circulating hormone stimulated by volume loading. Nature (Lond.). 314:264-266.

25. Schiffrin, E. L., J. Gutkowska, O. Kuchel, M. Cantin, and J. Genest. 1985. Plasma concentration of atrial natriuretic factor in a patient with paroxysmal atrial tachycardia. N. Engl. J. Med. 312:1196.

26. Yamaji, T., M. Ishibashi, H. Nakaoka, K. Imataka, M. Amano, and J. Fujii. 1985. Possible role for atrial natriuretic peptide in polyuria associated with paroxysmal atrial arrhythmia. Lancet. i:1211. 